Journal of Southeast Asian

Volume 15

Issue 2 Voices from the Field: Centering

Southeast Asian Americans through Policy,

Article 6

Practice, and Activism

2020

\title{
Vietnamese American Women Public School Administrators Leading for Social Justice and Equity
}

Jia Grace Liang

Kansas State University, gliang15@ksu.edu

Follow this and additional works at: https://docs.lib.purdue.edu/jsaaea

Part of the Educational Leadership Commons

\section{Recommended Citation}

Liang, Jia Grace (2020) "Vietnamese American Women Public School Administrators Leading for Social Justice and Equity," Journal of Southeast Asian American Education and Advancement: Vol. 15 : Iss. 2, Article 6.

DOI: $10.7771 / 2153-8999.1204$

Available at: https://docs.lib.purdue.edu/jsaaea/vol15/iss2/6

This document has been made available through Purdue e-Pubs, a service of the Purdue University Libraries.

Please contact epubs@purdue.edu for additional information.

This is an Open Access journal. This means that it uses a funding model that does not charge readers or their institutions for access. Readers may freely read, download, copy, distribute, print, search, or link to the full texts of articles. This journal is covered under the CC BY-NC-ND license. 


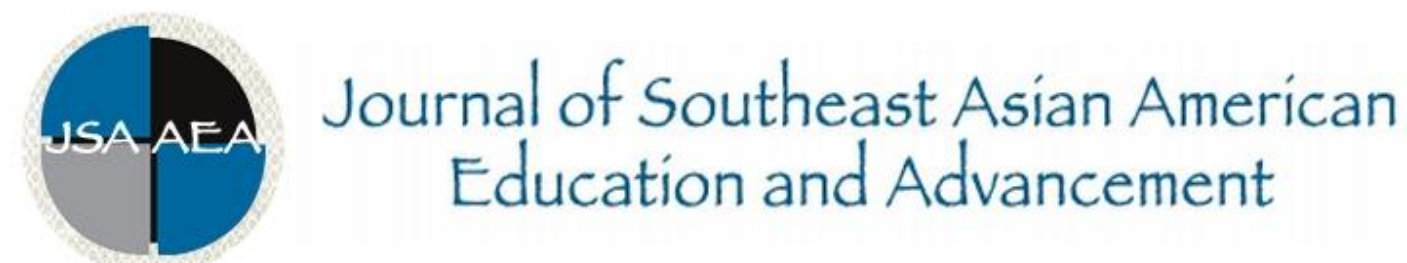

Vol. 15 Iss. 2 Special Issue (2020) www.JSAAEA.org

\title{
Vietnamese American Women Public School Administrators Leading for Social Justice and Equity
}

\author{
Jia Grace Liang \\ Kansas State University
}

\begin{abstract}
In the field of educational leadership, little is known about Southeast Asian American women, their perspectives and experiences as school leaders. Studies that explore the roles of Southeast Asian American women school administrators in leading for social justice are virtually non-existent. The current study was guided by the paradigm of transnational feminism. This qualitative multi-case study draws on retrospective accounts of two Vietnamese American women school administrators in a Southern state and a Midwestern state to understand the ways in which they navigate intersectional stereotypes in their leadership context to advocate for and create conditions for educational equity for their socioculturally and linguistically diverse students and families.
\end{abstract}

Keywords: Southeast Asian Americans, Women leadership, Social justice, Qualitative research

\section{Introduction}

Despite being the fastest growing population in the United States with a projected 200\% growth rate by the year 2050 (USCB, 2011), Asian Americans continue to represent a small segment of the teaching force, unable to keep pace with the growing rates of Asian American students in the K-12 educational pipeline (Chong, 2002). The limited literature on Asian Americans in the teaching force and educational leadership has focused on the Chinese, Japanese, and South Korean ethnic groups (Endo, 2015; Goodwin, Genishi, Asher, \& Woo, 2005; Pacis, 2005; Park, 2009). Furthermore, almost all the literature on discriminations toward Asian Americans and associated with race, gender, and nation/immigration status in the field of education has focused on students or education of the pan-ethnic group (Fan, 2009; Lew, 2006; Uy, 2008; Wright \& Boun, 2011); there are a few exceptions that specifically attend to Southeast Asian Americans (e.g., Ngo \& Lee, 2007) or Pacific Islanders (e.g., Pang \& Cheng, 1998; Pang, Han, \& Pang, 2011). In this paper, while it is not my intention to take lightly the reality that Asian Americans continue to be

\footnotetext{
(a)

SDREAIGHISRESEREEDReaders are free to copy, display, and distribute this article, as long as the work is attributed to the author(s) and the Journal of Southeast Asian American Education \& Advancement, it is distributed for non-commercial purposes only, and no alteration or transformation is made in the work. More details of this Creative Commons license are available at http://creativecommons.org/licenses/by-nc-nd/3.0/. All other uses must be approved by the author(s) or JSAAEA. Journal of Southeast Asian American Education \& Advancement, Vol. 15. Iss. 2. (2020) ISSN: 2153-8999
} 
marginalized or excluded in policy discussions to diversify the teaching and leading forces (Museus, 2009; Wu, 2014), it is my intention to argue that it is equally critical to recognize and honor the unique and complex history, experience, culture, agency, and contributions of Southeast Asian Americans - one that is often rendered invisible under the pan-ethnic category of Asian Americans or essentialized as one-dimensionally and pathologically "at risk," as portrayed in the dominant refugee discourse about the group.

In the field of educational leadership, little is known about Southeast Asian American women, their perspectives and experiences as school leaders. Studies that explore the roles of Southeast Asian American women school administrators in leading for social justice are virtually non-existent. The sparse literature available on Asian American educators in general and Southeast Asian Americans in particular has been the case where the researchers have situated their work in the long, cultural history of experiences of close-knit immigrant communities in regions such as the coastal states in the United States (Nguyen, 2008; Pang, 2009). The study reported here drew on retrospective accounts of two Vietnamese American women school administrators in a Southern state and a Midwestern state to understand the ways in which they have navigated intersectional stereotypes in their leadership context to advocate for and create conditions for educational equity for their socioculturally and linguistically diverse students and families. In contrast to a locale such as California, the two women have assumed leadership in a context where even the presence of the general Asian American communities is limited, affecting the likely supplies of social capitals and conditions for access to, advancement in, and enactment of leadership in educational systems.

\section{Southeast Asian Americans and Vietnamese Americans}

Under the banner of Southeast Asian Americans are ethnically diverse groups comprised of Vietnamese, Chinese, Thai, Khmer (Cambodian), Laotians, Hmong, Mien, and other ethnic minority tribes. Each group has their rich and distinct sociocultural and linguistic backgrounds, and other traditions and histories. Nonetheless, the majority of Southeast Asian Americans shares a common immigration history, which is known as the Vietnam War (1954-1975). The U.S. government's military and political attempts to control the perceived spread of the communism in the region produced a massive refugee population (Grewal, 2005). As a result, between 1975 and 1994, the United States received over 1,250,000 refugees from Southeast Asia. The Geneva Convention defines a refugee as "someone who is unable or unwilling to return to their country of origin owing to a well-founded fear of being persecuted for reasons of race, religion, nationality, membership of a particular social group, or political opinion" (UNHCR, 1951).

According to Takaki (1989), there were only several hundred people of Vietnamese descent living in the United States about half century ago. Since the end of the Vietnam War in 1975 where 130,000 Vietnamese entered the United States as refugees, the Vietnamese immigrant population has increased from 20,000 a year to 29,000 a year (Yamane, 2012). Today, Vietnamese Americans are the fourth largest Asian American ethnic group behind the Chinese, Asian Indians, and Filipinos. In examining 2000 Census data, Yamane (2012) found that Vietnamese immigrants, male and female, are significantly much less likely to hold managerial and supervisory positions than comparable East European immigrants. The glass ceiling for Vietnamese Americans is not restricted to any part of the country (Yamane, 2012). Foreign-born Vietnamese women face even more wage discrimination than Vietnamese men (Yamane, 2012). Furthermore, research on Southeast Asians residing in the United States is limited and predominantly casts this population 
as "problems," noting high poverty, lack of education, drug and/or alcohol issues, high youth pregnancy rate, youth delinquency, gang activities and violence, and economic instability (Lee, 1994; Morrow, 1989). Such phenomenon has been critiqued by critical refugee studies scholars as not only partial but also pathological representations of the populations and their traditions/cultures (Espiritu, 2014; Espiritu \& Duong, 2018; Um, 2012). Moreover, such portrayals of Southeast Asian American refugees are racialized and gendered, where girls and women are biopolitically articulated as subjects of violence needing the protection of the Westerners and boys are cast as prone to acting on violence and as such posing a potential risk or threat to themselves and othersleading manufactured justifications for harsh disciplinary actions such as incarceration (Grewal, 2005).

The current study was informed by the paradigm of transnational feminism, an anchoring epistemological point, albeit not necessarily in the exact vocabularies/terminologies, from which the two women administrators in the study have approached their work at their schools. Built upon postcolonial feminist theories, transnational feminism further complicates global capitalism and neoliberalism by taking an intersectional approach to understand gender, the state, race, class, and sexuality and their roles in problematizing and resisting the ideologies, structures, and practices of patriarchal and capitalist power (Alexander \& Mohanty, 1997, 2010; Grewal \& Kaplan, 1994; Mohanty, 2003). The present article aims to extend our collective understanding of leadership of Southeast Asian American women in education. As such, I explore the complexities of the two Vietnamese American women administrators' being and leading in the mainstream classroom, namely, (a) the women's negotiation of racialized and gendered expectations across administrative roles, (b) the women's orientation to leadership and its development, and (c) the interplay between (a) and (b) in the women's actualization of social justice in leading.

\section{Research Methodology and Context}

The current study draws upon existing data from a larger study that examined the experience of Asian American women administrators of K-12 public schools in multiple states. Purposive sampling (Patton, 2002) was used for participant selection in the larger study to recruit Asian American women school administrators who are able and willing to share with the research team their development of, orientation to, and experiences of leading in schools. Intentional effort was made to maximize the variation in geographic location, immigrant generational status, and ethnicity. Due to the lack of public information available on the group, the research team had to rely on personal and professional connections with multiple agencies and professional networks to conduct the initial recruitment and purposive sampling procedure. In the end, the larger study included three states (one Southern state and two Mid-Western states) and participants from seven Asian ethnic groups (Chinese, Korean, Japanese, Thai, Vietnamese, Indian, and Filipino). During the data collection and preliminary data analysis stage, it became apparent that the two women administrators included in this paper not only self-identified as Southeast Asian Americans but also were very articulate about refugee experiences, specifically how such identification and "transnational journey" have shaped their orientation to, development of, and enactment of leadership in relation to their refugee and other minoritized students and their families. Further, these two women administrators' self-reported commitment to social justice and equity were supported by the verification and recommendation the research team received from their colleagues. As such, for the purposes of this study, the two Vietnamese American women assistant principals served as instrumental cases to gain deeper knowledge of a particular event or context 
(Stake, 2006), that is, Southeast Asian American women leading for social justice in urban schools. A case, defined as a bounded system, is to provide a deeper understanding not only of the context but also of the issues that defines the context (Stake, 2006). Each woman assistant principal represents a case.

The two women, Linh and Puong (pseudonyms), though shared a strong commitment to leadership for social justice as evident in the data, represented much contextualized understanding of and distinct paths to leadership for social justice. They had certain commonalities and variations in their demographic and professional backgrounds (see Table 1). The two schools they served as assistant principal shared certain characteristics but differed in others (see Table 2).

Table 1. Participant Demographics.

\begin{tabular}{lrr}
\hline & Linh & Puong \\
\hline Grade Level & Middle & High \\
Years of Experience in Education & $>20$ & $>20$ \\
Years of Experience in Administration ${ }^{*}$ & $>5$ but $<10$ & $>10$ \\
Years in Current Position & about 6 & about 10 \\
Highest Educational Level & Master's & Doctoral \\
Immigrant Generational Status & 1.5 Generation & 1st Generation \\
Age & $50+$ & late 40s \\
\hline
\end{tabular}

Note: *Administrative experiences include the women's years as department chair, program coordinator, curriculum coach, and to name a few. The 1.5 generation immigrants refer to those who migrated to the U.S. between the ages of 6 and 13, and the first generation refers to those migrated as adults (Rumbaut \& Rumbaut, 1976; Zhou, 1997).

Semi-structured in-depth interviews (Rubin \& Rubin, 2005) and field observations were conducted. Also collected were archival data on schools. I developed reflective memos throughout the fieldwork and analysis. Data analysis was ongoing. In the first cycle of coding, an "initial coding" method, incorporated with in vivo and process coding, was used to develop categories and subcategories from codes and iteratively revised codes or categories (Saldaña, 2016). In the second cycle, a "pattern coded" method was used to develop initial themes (Saldaña, 2016). Furthermore, an adapted constant comparative method (Strauss \& Corbin, 1990) was used to generate themes within and across each case and to compare data with the literature and theoretical frameworks to look for consistencies and discrepancies. Trustworthiness of the research was addressed by use of multiple sources of evidence, use of extensive analytic memos, and member check (Lincoln \& Guba, 1985).

Table 2. School Characteristics.

\begin{tabular}{lrrrrrrr}
\hline Entity Name & Enrollment & School & \multicolumn{2}{c}{ Students } & Teachers \\
\cline { 2 - 8 } & & Title I? & $\begin{array}{r}\% \\
\text { English } \\
\text { Learners }\end{array}$ & $\begin{array}{r}\text { Fr/R } \\
\text { Lunches }\end{array}$ & $\begin{array}{r}\text { Largest } \\
\text { Ethnic } \\
\text { Group }\end{array}$ & $\begin{array}{r}\text { Mumber } \\
\text { of }\end{array}$ & $\begin{array}{r}\text { Minority } \\
\text { Teachers }\end{array}$ \\
\hline Linh's School & 568 & Yes & 2.0 & 60.0 & White & 30.0 & 36 \\
District A & $29 \mathrm{~K}$ & & 20.1 & 59.0 & White & 45.0 & $2.1 \mathrm{~K}$ \\
Southern State & $1,634 \mathrm{~K}$ & & 8.1 & 57.0 & White & 56.0 & $115 \mathrm{~K}$ \\
Puong's school & 574 & Yes & 7.7 & 100 & Black & 100 & 38 \\
District B & $28.9 \mathrm{~K}$ & & 11.0 & 75.0 & Black & 89.0 & $2.2 \mathrm{~K}$ \\
Midwest State & $918 \mathrm{~K}$ & & 3.2 & 51.3 & White & 26.3 & $66.2 \mathrm{~K}$ \\
\hline
\end{tabular}

Note. For parsimony reasons, numbers are rounded up by thousand, when applicable. Fr/R: Free and reduced priced. 


\section{Findings}

Two prominent themes emerged from the data. The first theme speaks to the impactful effects of displacement that the women and their families have experienced as they migrated into the United States as refugees on the women's perspectives on identity, education, and leadership.

Both women spoke about the years of struggles that their families as a whole had faced once they "landed" in the United States. Despite their credentials and successful careers in the past, the women's parents were no longer recognized as highly skilled professionals in "this new land called the United States." "Everything seemed to be stripped away from us except for that we were known as refugees," Linh commented. Similarly, Puong remembered seeing her parents working multiple part-time jobs just to barely make ends meet. The fact was that, before the war, Puong's father was a flight attendant in Viet Nam, and was fluent in French and English; her mother was a French teacher. "They [her parents] just did not have the time and energy; I mean, they would have wanted to, like attending school events, checking on us about our school work." Puong shared; she and her other five siblings learned to rely on one another. Puong further noted, "And, we were the only few Asian kids in the school; a lot of time they [the administrators and teachers] didn't know how to deal with us." Likewise, Linh commented that her parents "really did not have the financial means for [her and her seven siblings] to explore anything else other than to go to school and go home." "We were pretty much swimming and sinking together as siblings, and we all struggled in schools," Linh said, "but, all of us did make it to college." The families' encounters of discriminatory employment situations did not stop them from putting high values on education. Both women emphasized that their parents insisted on them doing well in schools and provided every bit of means they could afford to support them. Education, as the women put it, was important and had become even more important as the families regarded it as "the way out of poverty" after they were in the United States. Yet, quality education was robbed from the children like the women in this study.

Both women noted the negative and subpar experiences they had with American schools. Puong mentioned that her accent was being ridiculed and she was bullied without intervention from the teachers and staff in schools:

The teachers and adults in charge never reprimanded the teens for the harassment and the bullying that they did to me in the hallways, even though they witnessed the acts many times. Either they looked away, though at times I had eye contact with them asking for help, or they just shooed the students along to the classes.

Puong explained that at the time, her siblings and she were the only English as Second or Other Languages (ESOL) students in the school and they did not have any programs to support their needs. Linh's experience was similar. Her teachers "did not know what to do with [her and her siblings];" what they did was "cut down the number of problems" or "skip assignments," and "that was about it." Even today, Linh remembered vividly that she "was crying every night with [her] big fat dictionary." "I missed out a lot curriculum because of how they did with us as the nonEnglish proficient. I was struggling big time." Linh stated, "So, by the time I got to high school, it was time to pick a major. My dream was to become a teacher; it was just shattered." Not only the English language curriculum and instruction were inadequate to say the least, the curricular in other subjects were also culturally insensitive and often a product of a colonial gaze (Grewal, 2005). For instance, Puong recalled, 
Learning about the Vietnam War was such an uncomfortable unit for me. I sat through the lessons feeling so uptight with anxiety, not knowing what the teacher and the classmates thought of me. I avoided looking at the history clips my teacher put on the screen.

The U.S. educational system was not established and operates with "all children are equal in mind;" as the critical scholars have pointed out low expectations and education debt that minority students are subjected to (Ladson-Billing, 2006; Park, Endo, \& Rong, 2009).

As teenagers, the women learned what the "refugee" label meant and experienced the inbetween space (Grewal, 2006; Mohanty, 2003); they had constantly to negotiate what "I" meant for themselves and how "I" was expected from them by others, the dominant group, and the sociopolitical circumstances in the state-nation arenas. At times, as a coping mechanism, the women would try to escape the negativity associated with being labelled as a refugee by behaving more like a "model minority," a seemingly "positive" image of the Asian Americans. Puong shared:

The Vietnam War had left a forever mark on me. You know, people ask the where-areyou-from question; I would say, "I came from China." I chose China as a temporary homeland because I believed that most Americans associated the Vietnamese with savages from the images that were portrayed in movies and media at the time. I denied my roots because I did not want to be labeled as savage. I was thirteen then.

Linh ended up with choosing a STEM major, noting, "I played it safe by choosing software engineering in my undergraduate studies; you know, that was expected-model minorities to do well in math and science; so, no question, no hassle."

These autobiographic and schooling experiences have taught the women that they are always racialized, transnational subjects in the U.S. society. That has played an undeniable role in shaping the women's aspiration for leadership. They were keenly aware that they were the few, if not the only, "of [their] kind" in a space predominantly occupied by people who do not look like them. Puong noted:

It was almost a decade before I stepped into the entry level of educational leadership role of an instructional coach in the same district I taught. I was not surprised to learn that I was the only Asian American in the leadership role in the district, period. That was 2008, and our district was one of the biggest districts in the Midwest.

Linh also came to educational leadership late in age as she had a different career before, not necessarily by choice, as noted above. Nonetheless, she never gave up; once she learned that she could do so through alternative licensure, she went back and got her teaching credential. "That was my best decision; I never looked back." Linh said. For both women, becoming a school administrator was a way to make a difference and do so in a larger scale beyond their respective classrooms as a teacher. The following quote well captured Puong's reason for pursing leadership:

Throughout my life, especially in those teaching years, I often found myself having to pick a side, either siding with the White or the Black, but I am neither. I knew how that felt even as a child; I just did not have the language. When I was in my 
doctoral program, I learned about Black women, how they could and had transformed the power that was intended as a mechanism for oppression into an effective vehicle for change. "They rock the boat and stay in the boat." [Lorde, 1984] Could Asian American women, a Vietnamese American woman like me, rock the boat and stay in the boat?

What Puong referred to was the notion of "tempered radicalism" by Meyerson and Scully (1995), where people who are tempered radicals are "individuals who identify with and are committed to their organizations and also to a cause, community, or ideology that is fundamentally different from, and possibly at odds with the dominant culture of their organization (Meyerson \& Scully, 1995, p. 586). Likewise, Linh believed that change, especially those demanding systemic shifts in mind and action, demands "dare to dream." She stressed,

Because the existing systems are not equitable-you know the saying, "The master's tools will never dismantle the master's house" [Lorde, 1984]; we have to have hope and courage to envision something different, non-exist, and we have to be brave enough to act on them. This may sound cliché, but I am mother to two beautiful daughters; and my students are my children too. Am I selfish or greedy by wanting all of them to grow up knowing they can be anything they want to be?! And having quality education that allows them to do so?! Despite the obstacles that they may have?!

Both women's perspectives on leadership showed a strong orientation to social justice. When asked how she would define leadership, Linh shared, "Leadership is not about a position. For me, it is an outlet that allows me to turn my love for and commitment to the minoritized children to real actions." "To make a difference; to level the playground as much as I can." Linh further added, "Honestly, it really started simply as, 'I see myself in them.' I couldn't pretend that our educational systems treat every child the same. They are NOT." Likewise, in addition to being very intentional in choosing a social justice oriented doctoral program to get her leadership degree, Puong was also very adamant in the type of schools that she wanted to work as a teacher and later a school administrator. "I am not saying one can't do social justice work in other types of schools, the wellresourced, the quote-and-quote 'well-performed' ... it is just not for me. They don't need me. You know what I mean." Puong noted, "My kids, I mean the students I have taught and served, theyI want to be there with them and for them."

Furthermore, the women administrators believed that the experiential relatability and affective connections they had with their minoritized students and families not only played an undeniable role in first igniting their interest in leadership but more importantly became "the moral grounding," as Linh put it, over the years to sustain them through challenges and touch times. In their entrance to and advancement in leadership, the two women administrators received no mentorship. "No one really took interest in me and took me under their wings. I guess, they look at me and thought, I was too different." Puong said. Later in the interview, Puong also shared, "All these years, I still have to remind myself from time to time that why I am here and for whom-I am a human; I get fatigue and feel drained fighting injustice. My students give me the best reason to keep fighting." Likewise, Linh had to rely on herself: "You know that kind of feelings? Feeling so lonely and invisible even when you are surrounded by people? I didn't have those people, what you call, mentors or sponsors who wanted to help and groom me to be an administrator." Linh 
explained, "You just couldn't help but wonder, why is that? Can't you see that I have the passion? I want to be better for the kids?" Linh credited her being very observant as an important means that she developed her leadership capacity, besides formal education received from her credential programs. While Linh still considered herself a "shy and introvert" person, she remarked that her love for her students gave her strengths to be "outspoken" and "fearless:"

There were suspicions, accusations from some parents, staff ... I had a personal agenda. I felt so hurt; after all I have done, how could they not see that I care about the kids, the school so much and put in a lot work ... But, in my heart, I have never changed a bit-I am here to serve the kids. That makes it easier to accept what is going on. I mean, if fighting a lifetime battle for justice means that my career will take a hit along the way, then I am okay with it.

Moreover, often as the only or one of the few Asian Americans, not to mention Southeast Asian Americans, in their schools and districts, the two women were subjected to constant scrutiny and questioning regarding their leadership competency and their authority as an administrator. Puong mentioned that, after many years of being an administrator, she still encounters circumstances where people automatically disqualified her as a school leader because of her "darker skin" as a Southeast Asian female, speaking English with an accent, and having a "soft communicative style." For instance, she recalled attending a district meeting where the office clerk thought she worked at the cafeteria,

She [the clerk] told me that I was in the wrong place, even when I had my name tag on. I did not react as I was shocked as in disbelief. Then, she raised her voice, "Do you understand me?” Really? Supposing that I did not understand English, but I am not deaf!

Both women were aware of the stereotypes associated with Asian American women in general and Southeast Asian women specifically. For instance, Linh said,

The stereotypes of Asian American women are that she is docile, weak, and quiet like a demure wife, or she is manipulative or an overachiever who goes to the Ivy League schools for all her education. When it comes to Southeast Asian women, people tend to associate us with limited education, ambition, and independence; they don't think us as intelligent; they see us as speaking broken English and working in low paying jobs such as laundromat. You know, we, Vietnamese Americans, are called "boat people" by the mainstream media. Is that ironic or what? Like we did not have a life in a country full of culture and history before war and being forced to exit and come to America!

Linh recalled that at meetings, some male colleagues would not even formally introduce themselves to her even after she had introduced herself to them. "You could say that they did not know what to make of me. This body of mine was not supposed to be in 'their space' - the space called administration." Linh stated, "It was not what they expected of a Vietnamese American woman." Both women administrators spoke about that they had to walk in a fine line of being viewed as "too soft" or being "too demanding" - in other words, too manly or un-womanlike. At 
times, they had to "be really articulate or really assertive in order to make a point and to be heard." The women administrators noted that male leaders were treated differently and certain leadership styles were valued more. For instance, Puong remembered:

People above me thought that I was too soft or too friendly ... I feel like the mainstream culture depicts a different set of criteria. People tend to view an assertive leader as being authoritative or potentially an influential icon ... Male administrators have more permission or are more accepted, if they start to sound a little more sophisticated right off the bat. They can be direct and they are allowed to say the things that they want to say right off the bat, with no patting.

And yet, when the women administrators' approaches or styles were more forthright, they were perceived to be "unnecessarily perfectionist," "coming [on] to strong," and needed to "soften up."

The second theme relates to that the two women leaders strategically break the silence of Southeast Asian Refugee experiences to create space for collective remembering, redefining, and healing. They are able to do so because they understand such silence and are willing to be vulnerable by relying on their own personal experiences as refugees and Vietnamese American women to connect and build a community. Further, they have exerted their commitment to and actualization of social justice through critical care as manifested in high expectations, nurturing resilience, and promoting communal/critical pedagogies.

Linh recalled growing up her parents rarely talked about the war and all the losses they (and their extended families) had borne. As noted by critical refugee scholars (Espiritu, 2014; Espiritu \& Duong, 2018), the generation who come of age post-war face the "fractures caused by these traumas live on in the forms of silences and erasures in published forms of history as well as within the families who survived these traumas" (Chuong, 2019, p. 7). Linh stated,

That was something we, I mean myself and my siblings, just knew not to go there. We understood that as my parents tried to protect us from all the violence occurred and pains could be inflicted by telling us what happened. We understood very early on that our parents have given up so much so that we could have a better life in this new land. The lost would never be recovered and has left wounds forever deep and raw.

Likewise, Puong shared such experiences of losing loved ones in the extended families. These common narratives shared by the two participants speak directly to the phenomenon of normalizing silence that is significant to the Southeast Asian American community, when members only understand the silences as trauma-filled (Chuong, 2019). And yet, more importantly, as critical refugee scholars and Southeast Asian American studies scholars highlight the tensions of remembering and existing in silence (Espiritu, 2014; Um, 2012), arguing that silences are not an absence of telling and instead, they communicate history from one generation to the next. The women had developed different ways to remembering and existing in such appeared-to-be silence. Though could not recall what triggered it, Puong began to journal about things that happened and her thoughts after a few years in the United States. It has become what she called "a safe place for 'me-and-me' dialogues." "I guess I was trying to figure who I am; you know, as a teenager I was curious and confused;" Puong stated, "sometimes they saw me as this poor refugee kid, clueless and needed all the help they could give me; then other times, they 
expected me to be a math whiz, excelling everything. But I was neither." For Puong, journaling was a channel for the then young her to process her racialized and transnational experiences under the dominant biopolitical and geopolitical discourses in the United States. It was until about over a decade ago when she enrolled in a doctoral seminar, she found a language for that. "My stories reflect what underlies CRT [critical race theory];" Puong noted, "there is a part about being Asian Americans in a white dominant society; and there is a part about Southeast Asian Americans, our shared forced departure and loss, materially and psychologically, and generations of re-building, re-identifying, and re-living."

In Puong's school, under her leadership, "a quiet room" was established for students and their families if they would like some quiet time individually or collectively. Faculty and students (and families) knew she writes personal journals, and understood that the room signals her and the school's commitment to "recognize and acknowledge one's stories and pains, one's individual and collective journey to memory, awareness, and agency." With the support from the principal, Puong made sure that they would have at least two guest speakers from the communities of color invited to the school for teachers and/or students, sharing their social justice perspectives and advocacy work. Gradually, Puong was able to change how holidays such as Black History Month or Columbus Day were celebrated in her school. The celebrations were no longer just superficial food events and/or with people dressing up in traditional clothing; rather, a revisit of history behind the holiday and addressing modern-day manifestations of such oppressive "legacies" were the focus and made into activities such as mini theatres so that the participants could have embodied experiences of remembering, reflecting, and honoring. When it comes to students, there was nothing small. Puong's own experiences of being "Other" have led her to be very conscious of such othering practices (Kumashiro, 2000). For instance, Puong recalled the following instance that happened at a leadership team meeting:

The accountability report was passed around. For the demographic data section, the races of students were listed as Asian, Black, Hispanic, American Indian, White, and Other. The word "Other" caught my attention immediately. ... I had to say something. Could we stop reporting "Other" in our demographic section? How difficulty is it to count for one school? We do it with Whites, Blacks, Hispanics, ...; we can do the same for the students who are classified as "Other." "Why? That's how the district reports ..." an administrative staff interrupted. "We need to start here at our school and now." I did not budge, It's not a good feeling knowing that you're being classified as "Other." I was one of them. Are we saying to these students that they are less a human being than the other races or ethnicities?

Informed by her own critical consciousness, Puong was able to problematize the norms and reject creating "the minoritized within the minorities"- one that is not alien to Southeast Asian Americans' experiences (Espiritu, 2014; Ngo \& Lee, 2007; Um, 2012). Furthermore, though working as an assistant principal in a majority African American/Black neighborhood, rather than being handicapped by her perceived racial difference from the community, Puong's literacy in her racial self and the ways schools operate in racialized contexts enabled her to recognize their shared history at the intersections of race and immigration and use such collective memories for building alliances with the Black communities she serves.

Like Puong, Linh's leadership and advocacy for her minoritized students clearly echoed the notion of storytelling as "a feminist praxis of intimacy, alternative intergenerational memories 
are created to break silences and simultaneously create communal intimacy/connections as a force of resilience" (Chuong, 2019, p. 13). Though did not necessarily use the exact language of storytelling, Linh's ways of relationship building, community-based empowerment, and healing were anchored on collectivity, criticality, and self-agency. In Linh's school, the top three language represented were English, Spanish, and Vietnamese. With a substantial refugee student population, Linh understood that many of her staff (predominantly white) were not prepared to educate, support, and empower their students with their mainstream teacher preparations. In addition to insist on high expectations on all students, Linh had to be creative in obtaining external resources such as applying for grants to support continuous professional development for her staffs - which she sort of jokingly called "reprograming," to challenge their discriminatory way of thinking and practice, be it unconsciously or seemingly well-intentioned. She was able to secure partnerships with local businesses to help with scholarships so that the children whose families were underresourced could go on field trips. She was able to use a small grant secured from a non-profit organization to send her social studies teachers to workshops that were organized by Vietnamese advocacy organizations so that they could bring back "the community's perspectives" and included and centered them in the curriculum. Recognizing that many of her students of color were also caretakers for their younger siblings and language brokers for their non-English speaking parents, Linh, in collaboration with her principal and English language teachers primarily as well as some other staffs, had secured donated appliances and volunteers from the neighboring communities and enterprises. These resources were used to create an after-school center, where the students and their families could get assistance in things like homework, laundry, document filing, and babysitting. Also, Linh was not afraid to challenge the status quo of knowledge production - that is, who is the legitimate knowledge producer and what is the legitimate knowledge. Over the years, she made one consistent request in her welcome-back message to all her students: "Cherish your intergenerational memory. Keep it alive and strong by talking to your parents, elders, extended families, and/or someone you look up to in your community." Such a practice is critical, for, according to Chuong (2019), "many of the displaced and oppressed, the history of one's community is what lives on in intergenerational memory. As such, as one engages in ethnic culture and doing memory work can lead to liberation and empowerment" (p. 13).

Both Linh and Puong learned from their minority status to reject deficit thinking about their minoritized students and families; their personal awareness of and experiences with the agony of multiple injustices had helped them to appreciate diversity more. Both women displayed a genuine concern for their students' well-being and trusted their students' abilities to learn, showing sensitivity toward their students and the community's social concerns. The women had high expectations for their students. For instance, Puong would openly celebrate every accomplishment, small or big, any one of her students had, as part of her routine morning announcements. Over the years, she had used up eight thick notebooks filled with such information. "I want them [her students of color] to know they can be anything they want to be. They are much more sharper and resilient than the society, I mean, many people would give them credit for." Puong shared. For the two women, they wanted the best for their students, especially those of the minoritized, and the most rewarding thing was to see their students succeed academically and in life. Ensuring their students to have caring and quality teachers was noted by both women as their high priorities. While acknowledging hiring (and discharging as well) a faculty member or staff rarely a straightforward and simply task without extraneous intervening factors, both Linh and Puong stressed the importance of one's having "right mind and heart." For instance, one of the documents shared by Linh was her notes from a teacher candidate interview. The notes did not contain any 
personally identifiable information, but what stood out for me was some of the questions she asked, for example, "How would you define 'hope'?" "Could you tell me what 'an ideal student' would be like for you and why?" Furthermore, the two women administrators were cognitive that they, at times, were "quiet" about the discriminations and injustice toward themselves. "That is a sacrifice, for lack of a better term, that I have decided to burden some years ago. I learned the lesson the hard way when I was still a teacher; I thought my passion could overcome anything." Linh shared, "Why would anyone want justice and equity for all children? Did we all say that? I was not re-hired. Now, what? I couldn't' do anything for those kids I cared so much and was trying to fight for." Puong had similar comments,

I am much bolder when it comes to advocate and fight for my students and parents. Over the years, I have learned to do so very intentionally and strategically. Being an administrator gives me entry to spaces that I would not have otherwise; I am not gonna give it up easily, not for something related or about me. I am gonna use that for my kids.

The two women did so as "choosing your battle wisely" so that they could "remain their seats on the decision-making table," as Linh put it, to advocate for their refugee and minoritized students and their families. This is not to suggest that such approach or "inaction" had no consequences, but rather, it shows the women understood the discriminatory nature of the educational systems and had to learn to negotiate and push through in actualizing their commitment to social justice leadership.

\section{Conclusion}

This study contributes to the larger body of research on women in educational leadership by filling the significant gap in the literature on Southeast Asian American women school leaders. The findings have high relevancy for nowadays schools where the student populations become more and more diverse and challenges encountered become increasingly complex and with enduring impacts, in that they shed light on how these women negotiate their racial-ethnic and professional roles within the educational systems, and how they lead and navigate the landscape of school administration for educational equity. Also, the findings from this study have important implications for leadership development - the field can benefit from raising consciousness of nation, race-ethnicity, and gender in future and current school leaders; the field needs to recruit and develop leaders who embrace and exercise criticality in consciousness, exerting their leadership to establish culture and practice in schools that bring equity and justice.

To conclude, I use a poem entitled "Home We Made" to honor the bravery and resilience of these women leaders and the Vietnamese American community. The poem was inspired by the art work by Trinh Mai, a Vietnamese American artist, the presentation by Yến Lê Espiritu, ${ }^{1}$ a Vietnamese American critical scholar, and mostly the stories and spirit shared by my participants, aspirations for me and many.

where is home?

black hole, sucking every bit of breath, memory, life

boat, floating, see no ends or land

white strips, hanging down from the ceiling, ${ }^{2}$ 
museum, covered, awing faces and fancy suits and dresses tears dried, yet scars deep and raw

young sisters and brothers, nowhere to find, ever

this Little Saigon, trapped and yet a home made afar;

"insulation", finally a memorial in public

hugs so often and tightly, my children, life honored,

guarded so cautiously and hopefully, my school, a home made afar and in-between

\section{Notes}

1. Espiritu, Y. L. (2018, March 19). Feminist refugee epistemology: Reading displacement in Vietnamese and Syrian refugee art. Presented as part of the Critical migration and refugee studies series, by the Center for the Study of Race and Ethnicity in America (CSREA), Brown University. Retrieved from: https://youtu.be/P8ulyPmX9FM

2. The exhibition, Insulation. Information gathered from video entitled "Honoring life: The work of Trinh Mai" by The Artist Odyssey, retrieved at https://vimeo.com/155899048 and from Trinh Mai's personal website (http://trinhmai.com/curriculum-vitae), specifically the exhibition, "Quiet," in the 2015 "Vietnamese focus: Generations of Stories" project hosted by the Old Orange County Courthouse Museum, Santa Ana, CA. Images retrieved from https://www.ocregister.com/2015/08/24/generations-of-stories-artifacts-photos-and-a-tatteredmap-piece-together-history-of-the-vietnamese-who-settled-here/

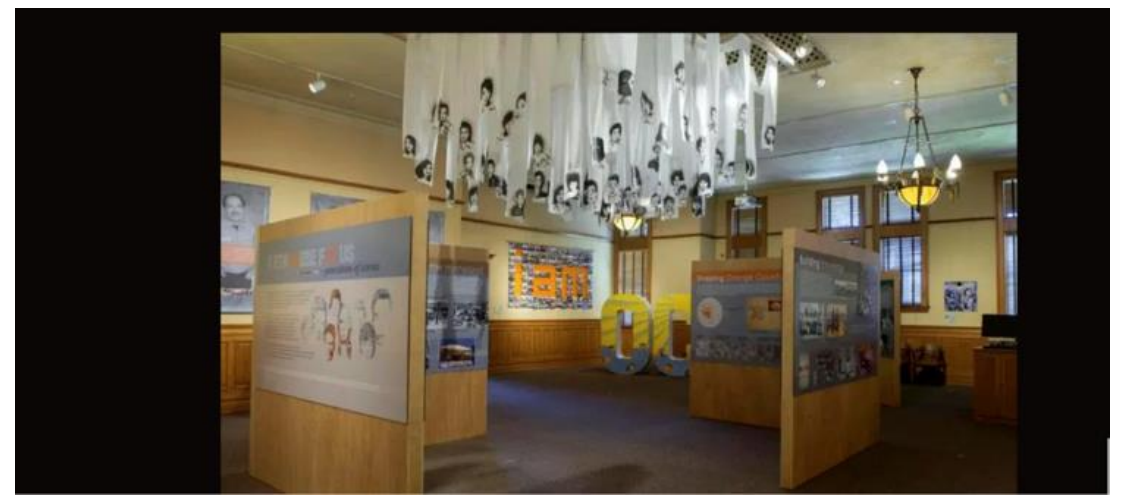

The Old Orange County Courthouse in Santa Ana features the exhibit "Vietnamese Focus: Generations of Stories," which includes artifacts, photographs, documents and art.

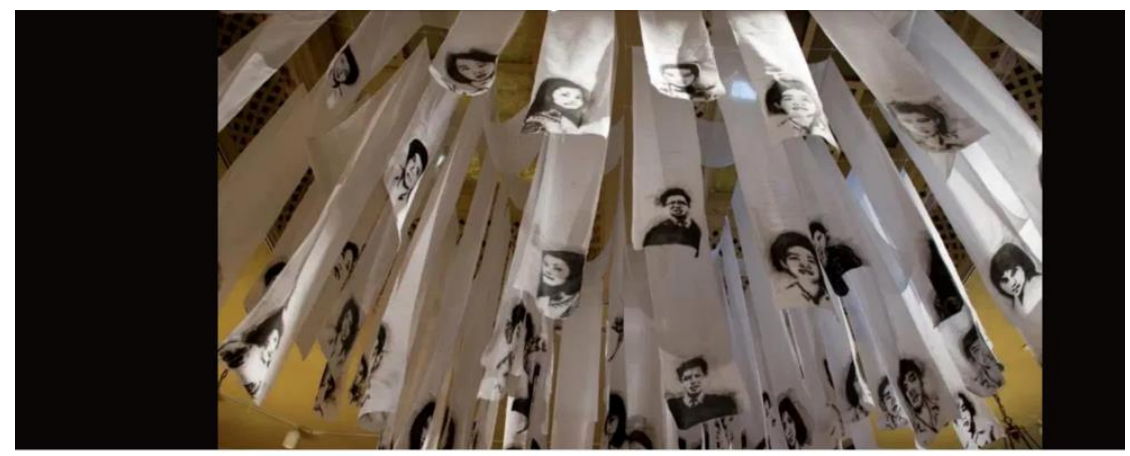

White sashes hang from the ceiling in the installation called "Quiet" by artist Trinh Mai, inspired by letters written by Vietnamese families looking for their loved ones 


\section{References}

Alexander, M. J., \& Mohanty, C. T. (Eds.). (1997). Feminist genealogies, colonial legacies, democratic futures. Routledge.

Alexander, M. J., \& Mohanty, C. T. (2010). Cartographies of knowledge and power: Transnational feminism as radical praxis. In A. L. Swarr \& R. Nagar (Eds.), Critical transnational feminist praxis (pp. 23-45). State University of New York Press.

Chong, S. (2002). Asian American teachers and teacher candidates in California: Who are they and what are their needs? In E. Tamura, V. Chattergy \& R. Endo (Eds.), Asian and Pacific Islander American education: Social, cultural, and historical contexts (pp. 117-131). Pacific Asia Press.

Chuong, S. (2019). SEA Us Rise: Feminist praxis of intimacy in Southeast Asian American youth organizing (Master's thesis in Asian American Studies), University of California, Irvine.

Endo, R. (2015). How Asian American female teachers experience racial microaggressions from pre-service preparation to their professional careers. The Urban Review, 47(4), 601-625.

Espiritu, Y. (2014). Body counts: The Vietnam war and militarized refuge(es). The University of California Press.

Espiritu, Y., \& Duong, L. (2018). Feminist refugee epistemology: Reading displacement in Vietnamese and Syrian refugee art. Signs, 14(3), 587-615.

Fan, Y. (2009). Lost in institution: A Vietnamese immigrant student learning to write in Midwestern urban mainstream classrooms. Journal of Southeast Asian American Education and Advancement, 4(1), 1-17.

Goodwin, A. L., Genishi, C., Asher, N., \& Woo, K. A. (2005). Voices from the margins: Asian American teachers' experiences in the profession. In C. Park, R. Endo, \& A. Goodwin (Eds.), Asian and Pacific Education: Learning, socialization, and identity (pp. 99-117). Information Age.

Grewal, I. (2005). Transnational America: Feminisms, diasporas, neoliberalisms. Duke University Press.

Grewal, I., \& Kaplan, C. (Eds.). (1994). Scattered hegenominies: Postmodernity and transnational feminist practices. University of Minnesota Press.

Kumashiro, K. K. (2000). Toward a theory of anti-oppressive education. Review of Educational Research, 70(1), 25-53.

Ladson-Billings, G. (2006). From the achievement gap to the education debt: Understanding achievement in U.S. schools. Educational Researcher, 35(7), 3-12.

Lee, S. (1994). Behind the model-minority stereotype: Voices of high- and low-achieving Asian American students. Anthropology \& Education Quarterly, 25, 413-429.

Lew, J. (2006). Asian Americans in class: Charting the achievement gap among Korean American youth. Teachers College Press.

Lorde, A. (1984). Sister outsider: Essays and speeches. Crossing Press.

Meyerson, D. E., \& Scully, M. (1995). Tempered radicalism and the politics of ambivalence and change. Organizational Science, 6(5), 585-600.

Mohanty, C. T. (2003). Feminism without borders. Duke University Press.

Morrow, R. (1989). Southeast Asian child rearing practices: Implications for child and youth care workers. Child and Youth Care Quarterly, 18(4), 273-287. 
Museus, S. D. (2009). A critical analysis of the exclusion of Asian American from higher education research and discourse. In L. Zhan (Ed.), Asian American voices: Engaging, empowering, and enabling (pp. 59-76). National League for Nursing Press.

Ngo, B., \& Lee, S. J. (2007). Complicating the image of model minority success: A review of Southeast Asian American education. Review of Educational Research, 77(4), 415-453.

Nguyen, H. T. (2008). Conceptions of teaching by five Vietnamese American preservice teachers. Journal of Language, Identity, and Education, 7, 113-136.

Pacis, D. C. (2005). Asian American females in educational leadership in K-12 public schools (Doctoral dissertation). Available from ProQuest Dissertations and Theses database. (UMI No. 305342434)

Pang, V. O. (2009). The beliefs of successful Asian American Pacific Islander teachers: How culture is embedded in their teaching. Asian American \& Pacific Islanders Nexus, 7(1), 5582.

Pang, V. O., \& Cheng, L. L. (1998). Struggling to be heard: The unmet needs of Asian Pacific American children. The State University of New York Press.

Pang, O. V., Han, P. P., \& Pang, J. M. (2011). Asian American and Pacific Islander students: Equity and the achievement gap. Educational Researcher, 40(8), 378-389.

Park, C. C. (2009). Korean Americans in the teaching profession. In C. Park, R. Endo, \& X. L. Rong (Eds.), New perspectives on Asian American parents, students, and teacher recruitment (pp. 123-136). Information Age.

Patton, M. Q. (2002). Qualitative research and evaluation methods (3 ${ }^{\text {rd }}$ ed.). Sage.

Rubin, H. J., \& Rubin, I. S. (2005). Qualitative interviewing: The art of hearing data (2 ${ }^{\text {nd }}$ ed.). Sage.

Rumbaut, R. D., \& Rumbaut, R. G. (1976). The family in exile: Expatriates in the United States. American Journal of Psychiatry, 133(4), 395-399.

Saldaña, J. (2016). The coding manual for qualitative researchers $\left(3^{\text {rd }}\right.$ ed.). Sage.

Stake, R. (2006). Multiple case study analysis. The Guilford Press.

Strauss, A., \& Corbin, J. M. (1990). Basics of qualitative research: Grounded theory procedures and techniques. Sage.

Takaki, R. (1989). Strangers from a different shore: A history of Asian American. Little, Brown and Company.

The Office of the United Nations High Commissioner for Refugees [UNHCR]. (1951). Convention and protocol relating to the status of refugees. Geneva, Switzerland.

Um, K. (2012). Exiled memory: History, identity, and remembering in Southeast Asia and Southeast Asian diaspora. Positions: Asia Critique, 20(3), 831-850.

United State Census Bureau [USCB]. (2011, April 29). Asian/Pacific American heritage month: May 2011.

Uy, P. S. (2008). [Special issue on SEA demographics] Response-K-12 education: How the American community survey informs our understanding of the Southeast Asian community: One teacher's perspective. Journal of Southeast Asian American Education and Advancement, 3(1), 44-50.

Wright, W. E., \& Boun, S. (2011). Southeast Asian American education 35 years after initial resettlement: Research report and policy recommendations: Conference report of the National Association for the Education and Advancement of Cambodian, Laotian, and Vietnamese Americans. Journal of Southeast Asian American Education and Advancement, 6(1), Article 1. 
Wu, E. D. (2014). The color of success: Asian Americans and the origins of the model minority. Princeton University Press.

Yamane, L. (2012). Labor market discrimination: Vietnamese immigrants. Journal of Southeast Asian American Education and Advancement, 7(1), Article 4.

Zhou, M. (1997). Growing up American: The challenge confronting immigrant children and children of immigrants. Annual Review of Sociology, 23, 63-95.

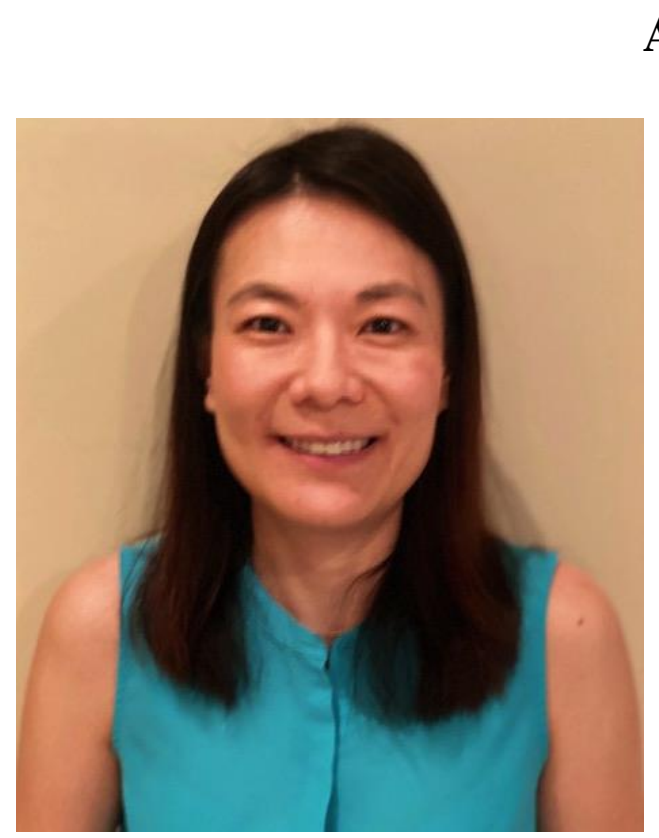

\section{About the Author}

Jia "Grace" Liang, is an Assistant Professor of Educational Leadership at the Kansas State University. She holds a PhD in Educational Administration and Policy along with a Master's in Educational Psychology from the University of Georgia and another Master's in Adult and Continuous Education from Marshall University. Her research and professional work focus on educational leadership and equity, particularly related to Asian Americans and Pacific Islanders, community engagement, capacity building in STEM, and intersectionality and women leadership. She currently serves as the treasurer of the Research on the Education and Asian and Pacific Americans SIG of the American Educational Research Association and the President-Elect of the Eastern Educational Research Association. Her work has appeared in leading journals and book chapters such as Educational Administration Quarterly, Journal of School Leadership, Gender and Education, International Journal of Mentoring and Coaching in Education, and Handbook of Urban Educational Leadership. 


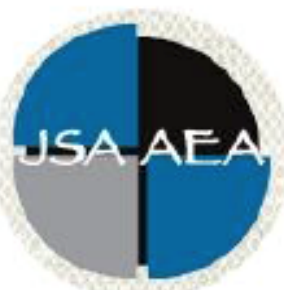

\title{
Journal of Southeast Asian American \\ Education and Advancement
}

Vol. 15 Iss. 2 Special Issue (2020) www.JSAAEA.org

Special Issue Co-Editors

Dr. Peter T. Keo

Stanford University

Dr. Loan Thi Dao

St. Mary's College of California

\section{Editor}

Dr. Wayne E. Wright

Purdue University

Associate Editors

Dr. Chhany Sak-Humphry

University of Hawaii at Manoa

Dr. Phitsamay Sychitkokhong Uy

University of Massachusetts, Lowell

\author{
Book Review Editor \\ Dr. Vichet Chhuon \\ University of Minnesota \\ Creative Works Editor \\ Bryan Thao Worra \\ Lao Assistance Center \\ Journal Manager \\ Fang Gao \\ Purdue University
}

\section{Editorial Review Board}

Dr. Steve Arounsack

California State University, Stanislaus

Dr. Sovicheth Boun

Salem State University
Dr. Carl L. Bankston III

Tulane University

Dr. Phala Chea

Lowell Public Schools 


\author{
Dr. Virak Chan \\ Purdue University \\ Dr. Loan Dao \\ St. Mary's College of California \\ Dr. Changming Duan \\ University of Missouri-Kansas City \\ Dr. Sothy Eng \\ Lehigh University \\ Dr. Vincent K. Her \\ University of Wisconsin, Eau Claire \\ Dr. Peter Nien-Chu Kiang \\ University of Massachusetts, Boston \\ Dr. Kevin K. Kumashiro \\ University of Illinois, Chicago \\ Dr. Ha Lam \\ Independent Scholar \\ Dr. Jonathan H. X. Lee \\ San Francisco State University \\ Dr. Monirith Ly \\ Royal University of Phnom Penh \\ Dr. Bic Ngo \\ University of Minnesota \\ Dr. Leakhena Nou \\ California State University, Long Beach \\ Dr. Mark Pfeifer \\ SUNY Institute of Technology \\ Dr. Loan T. Phan \\ University of New Hampshire \\ Dr. Karen Quintiliani \\ California State University, Long Beach \\ Dr. Angela Reyes \\ Hunter College \\ The City University of New York \\ Dr. Fay Shin \\ California State University, Long Beach \\ Dr. Christine Su \\ College of San Mateo \\ Dr. Alisia Tran \\ Arizona State University \\ Dr. Khatharya Um \\ University of California, Berkeley \\ Dr. Kim Tran \\ University of California, Los Angeles, \\ Glendale Community College \\ Dr. Molly Wiebie \\ The University of Texas at Austin
}

Dr. George Chigas

University of Massachusetts, Lowell

Dr. Hien Duc Do

San Jose State University

Dr. Sophal Ear

Occidental College

Dr. Jeremy Hein

University of Wisconsin, Eau Claire

Dr. Nancy H. Hornberger

University of Pennsylvania

Dr. Peter Tan Keo

Stanford University

Dr. Yvonne Kwan

San Jose State University

Dr. Ravy Lao

California State University, Los Angeles

Dr. Stacey Lee

University of Wisconsin, Madison

Dr. Sue Needham

California State University, Dominguez Hills

Dr. Max Niedzwiecki

Daylight Consulting Group

Dr. Clara Park

California State University, Northridge

Dr. Giang Pham

University of Massachusetts Amherst

Dr. Malaphone Phommasa

University of Clifornia Santa Barbara

Dr. Kalyani Rai

University of Wisconsin-Milwaukee

Dr. Cathy J. Schlund-Vials

University of Connecticut, Storrs

Dr. Nancy J. Smith-Hefner

Boston University

Dr. Yer J. Thao

Portland State University

Dr. Monica M. Trieu

Purdue University

Dr. Silvy Un

Saint Paul Public Schools

Dr. Linda Trinh Vo

University of California, Irvine

Dr. Yang Sao Xiong

The University of Wisconsin-Madison

Dr. Zha Blong Xiong

University of Minnesota 


\section{Doctoral Student Editorial Review Board}

\author{
Diana Chandara \\ University of Minnesota-TwinCiteis \\ Linh Dang \\ University of Rochester \\ Annie BichLoan Duong \\ San Joaquin County Office of Education \\ Jacqueline Mac \\ Indiana University \\ Vanessa Sovanika Na \\ University of California SanDiego \\ Khoi Nguyen \\ George Mason University \\ Linda Marie Pheng \\ University of Wisconsin-Madison \\ Latana Thaviseth \\ University of California Los Angeles \\ Melissa Vang \\ San Diego State University \\ Soua Xiong \\ San Diego State University \\ Claremont Graduate University
}

\author{
Kassandra Chhay \\ University of Minnesota-Twin Cities \\ Bao Diep \\ University of Minnesota-Twin Cities \\ Nielson Hul \\ Cornell University \\ Dung Minh Mao \\ University of Minnesota-Twin Cities \\ Hoa Nha Nguyen \\ Boston College \\ Thien-Huong Ninh \\ University of Southern California \\ Krissyvan Truong \\ Claremont Graduate University \\ Mai Vang \\ University of Massachusetts Boston \\ Thong Vang \\ University of Minnesota-Twin Cities
}

